\title{
Metal Alloys in Dentistry: An Outdated Material or Required for Oral Rehabilitation?
}

\author{
Aleaciones Metálicas en Odontología: ¿Un material \\ Excedido o Necesario para la Rehabilitación Oral?
}

\begin{abstract}
Jefferson David Melo de Matos; Andrezza Cristina Moura dos Santos²; Leonardo Jiro Nomura Nakano'; John Eversong Lucena de Vasconcelos ${ }^{3}$; Valdir Cabral Andrade ${ }^{4}$; Renato Sussumu Nishioka ${ }^{1}$; Marco Antonio Bottino ${ }^{1} \&$ Guilherme da Rocha Scalzer Lopes ${ }^{1}$
\end{abstract}

MATOS, J. D. M.; DOS SANTOS, A. C. M.; NAKANO, L. J. N.; DE VASCONCELOS, J. E. L.; ANDRADE, V. C.; NISHIOKA, R. S.; BOTTINO, M. A. \& LOPES, G. R. S. Metal alloys in dentistry: an outdated material or required for oral rehabilitation? Int. J. Odontostomat., 15(3):702-711, 2021.

ABSTRACT: The present study aims to describe through a literature review, the main types of noble and non-noble alloys in dentistry looking to identify the adhesion mechanisms, compositions and mechanical properties, and its applicability as a rehabilitation resource nowadays. A bibliographic search was conducted in the main health databases PUBMED (www.pubmed.gov) and Scholar Google (www.scholar.google.com.br), in which studies published from 1971 to 2021 were collected. Laboratory studies, case reports, systematic and literature reviews, which were developed in living individuals. Articles that did not deal with metal alloys and its use in dentistry were excluded. Through the review, it was possible to verify that all works presented the metal alloys and their main properties, indicating that they are divided into three main types: high noble alloys, noble alloys and base metal alloys differing in their levels of constituent noble metals. Several alloys and metals are available for the dental market each presenting advantages and disadvantages, mainly based on its specific composition.Continuous research and development are resulting in the production of new technologies and products, giving dental surgeons even more options in the design and manufacture of restorations using metal alloys and understanding that these resources will still be viable alternatives in oral rehabilitations. However, further studies on metal alloys are needed to better understand this subject.

KEY WORDS: dental alloys, metal ceramic alloys, dentistry, dental research.

\section{INTRODUCTION}

The classification of dental materials in dentistry is basically divided into three: Ceramics, polymers and metals. The metals when found in pure form constitute the metal alloys that are present in various dental instruments, prosthetic parts and in implants (Anusavice, 2013).

In 1774, Duchâteau used porcelain for the first time in dentistry, making a complete denture for himself (de Oliveira Bauer et al., 2004; Anusavice). Favorable aesthetics and biocompatibility are important characteristics of porcelain and favored its dental application (Marklund et al., 2003; de Oliveira Bauer et al.). However, these materials are highly friable, which does not allow use when subjected to great mechanical stress, as the risk of fracture is imminent (Akagi et al., 1992; Chain, 2013). In 1960, the favorable characteristics of porcelain were taken advantage of in view of the development of metal alloys, which led to the use of metal-ceramic restorations, which have

\footnotetext{
${ }^{1}$ Department of Dental Materials and Prosthodontics, São Paulo State University (Unesp), Institute of Science and Technology, São José dos Campos - SP, Brazil.

2 Department of Dental Materials and Prosthodontics, São Paulo University (USP), College of Dentistry, RibeirãoPreto - SP, Brazil.

${ }^{3}$ Department of Implantology of Prosthodontics, College of Dentistry CECAPE, Juazeiro do Norte - CE, Brazil.

${ }^{4}$ Department of Dentistry and Oral and Maxillo facial Surgery, Universidade Federal de Juiz de Fora UFJF, Governador Valadares - MG, Brazil.
}

Received: 2021-01-14 Accepted: 2021-03-17

702 
MATOS, J. D. M.; DOS SANTOS, A. C. M.; NAKANO, L. J. N.; DE VASCONCELOS, J. E. L.; ANDRADE, V. C.; NISHIOKA, R. S.; BOTTINO, M. A. \& LOPES, G. R. S. Metal alloys in dentistry: an outdated material or required for oral rehabilitation? Int. J. Odontostomat., 15(3):702-711, 2021.

since been undergoing technological advances in infrastructure and especially in terms of metal-porcelain adhesion, which remains a challenge for the final success of restorations (Callister Junior, 1994).

Metals are made up of a large number of equal atoms, with each atom surrounded by eight to twelve other atoms of the same metallic element, having equal attractions in all directions, which provides a crystalline structure (Chen et al., 2018). In this context, the atoms of metals have few electrons in the last electronic layer, consequently the electrons escape easily and pass freely through the crystalline lattice, in turn being called electron clouds, allowing the union of metal atoms (Hampel et al., 1971). Therefore, this structure in lattices and this type of chemical bond results in a series of properties that differentiate metals from other substances (Koizumi et al., 2019).

In addition, metals are chemical substances of mineral origin that are presented in dentistry for restorative, rehabilitating and surgical purposes, allowing an intimate relationship with the oral environment and guaranteeing the longevity of treatments (Roberts et al., 2009). However, they are subject to several physical-chemical and biomechanical changes (de Oliveira Bauer et al.; Anusavice). Noble metals have high resistance to corrosion, but their use in the form of alloy considerably increases their resistance to imposed stresses and, consequently, the physical properties and resistance to corrosion are improved (Vallittu \& Kokkonen, 1995). The compositions of the alloys are also extremely important to prevent corrosive effects and stains, due to chemical attacks promoted by the presence of metals in the oral oral cavity in direct contact with intraoral fluids, causing failures in oral rehabilitation (Wataha, 2001).

There are several properties of metals, which can highlight the brightness, malleability,ductibility, conduction of electricity and heat, high density, high melting and boiling points, tensile resistance, oxidation, corrosion and compression, surface hardness, flow that allows burnishing, low smelting shrinkage, biological compatibility, low cost, among others (de Oliveira Bauer et al.; Anusavice). Realizing the infinite properties that metal alloys had in the 1930s, base metal alloys were used for structures of removable partial dentures, since they have great advantages over noble alloys such as reduced cost and weight and can be offered in a wide range scale for the population in the various rehabilitation / restorative procedures nowadays (Wolfaardt \& Peters, 1992).
In dentistry, metal alloys can be classified according to the number of elements; when this number of components involves only two elements combined in their various proportions, we call them binary systems (Zwilsky \& Langer, 2001; Zineli et al., 2003). When it involves three or more elements, it is called tertiary (Zavanelli, 2000). Therefore, these components are related to numerous elements that make up the alloys (Tkachenko et al., 2014). The definition of highly noble alloys occurs when they contain 40 to $60 \%$ gold, iridium, platinum, rhodium, palladium, ruthenium and osmium (Valittu \& Kokkonen, 1995), unlike the predominantly basic or non-noble alloys, which have more than $75 \%$ of common components, be they Nickel-Chromium and Chromium-Cobalt (Okuno et al., 1989).

Due to the widespread use of metal alloys in dentistry, further studies are needed to deepen the knowledge about these dental materials. Therefore, through this literature review, it is intended to evaluate the main types of noble and non-noble alloys in dentistry looking for identify the adhesion mechanisms, compositions and mechanical properties, and its applicability as a rehabilitation resource nowadays.

\section{MATERIAL AND METHOD}

Source Selection. A bibliographic search was conducted in the main health databases Pubmed (www.pubmed.gov) and Scholar Google (www.scholar.google.com.br), in hich studies published from 1971 to 2021 were collected. In the first stage, the list of retrieved articles was examined by reading the titles and abstracts. In the second stage, the studies were selected by reading the full contents. Two authors (JDMM and LJNN) performed stages 1 and 2. Experimental, clinical, case-control, randomized controlled and laboratory cohort studies, case reports, systematic reviews and literature reviews, which were developed in living individuals, were included. Therefore, articles that did not deal with the subject in question, letters to the editor, opinion article, duplicated literature in databases and literature that did not address the variables under study, were excluded.

Data Source. Through bibliographic search 90 articles were selected, which 77 articles were extracted from PUBMED (www.pubmed.gov) and 13 Scholar Google (www.scholar.google.com.br). The following specific medical subject titles and keywords were used: Den- 
MATOS, J. D. M.; DOS SANTOS, A. C. M.; NAKANO, L. J. N.; DE VASCONCELOS, J. E. L.; ANDRADE, V. C.; NISHIOKA, R. S.; BOTTINO, M. A. \& LOPES, G. R. S. Metal alloys in dentistry: an outdated material or required for oral rehabilitation? Int. J. Odontostomat., 15(3):702-711, 2021.

tal alloys (DeCS/MeSH Terms); Metal Ceramic Alloys(DeCS/MeSH Terms); Dentistry (DeCS/MeSH Terms); Dental Research(DeCS/MeSH Terms) (Fig. 1).

According to Table I, it can be seen that the average publication of articles in the period from 1971 to 2021 from the Pubmed database was 2.41 and with a standard deviation of 2.08. While at Scholar Google, the average was 0.39 and the standard deviation 0.77 . Thus, it was possible to verify that there was a significant variation in the number of articles in both databases (Fig. 2).

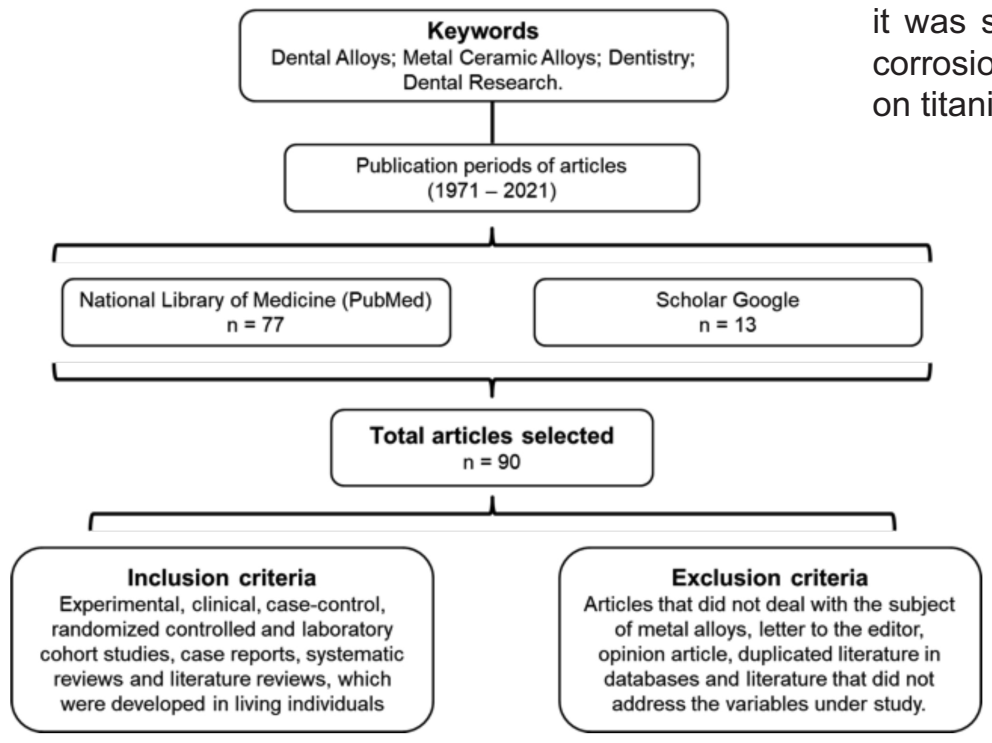

Fig. 1. Articles selection flowchart.
Table I. Mean \pm standard deviation of the number of studies in the main health databases.

\begin{tabular}{lcc}
\hline Database & $\begin{array}{c}\text { Mean } \pm \text { Stardard } \\
\text { Deviation }\end{array}$ & $\begin{array}{c}\text { Total Studies } \\
(1971-2021)\end{array}$ \\
\hline Pubmed & $2.41 \pm 2.08$ & 77 \\
Google Scholar & $0.39 \pm 0.77$ & 13 \\
\hline
\end{tabular}

\section{Total Per Year}

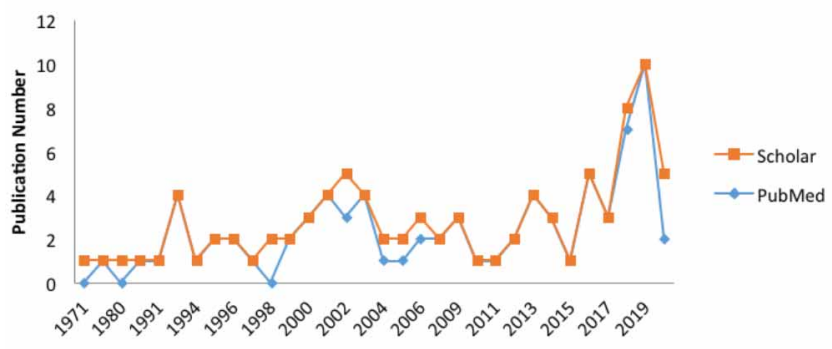

Fig. 2. Total articles published per year in the two main health databases.

\section{RESULTS AND DISCUSION}

Through the literature review, it was possible to verify that all works presented the metal alloys and their main properties, indicating that they are divided into three main types: high noble alloys, noble alloys and base metal alloys differing in their levels of constituent noble metals (McLean, 1980; Anusavice). The authors reported that for the use of alloys in metal-ceramic restorations, castability depends considerably on the structures present and also on special techniques and manipulations for different types of alloys. In addition, it was shown that silver-based alloys suffer greater corrosion among the available alloys and those based on titanium have the best properties.
Data analysis and integration. The metal alloys present in the dental market today must have the following fusibility properties; fracture toughness, corrosion, deflection; high mechanical resistance, so the professional who wants to rehabilitate patients with this resource must choose alloys with such requirements (Espevik et al., 1979). These materials are classified according to the levels of noble metals in their compositions, cost and mainly by the elements that compose them (Espevik et al.; Chen et al., 2016).
High noble alloys are present in dentistry for few patients, because due to their high cost they become inaccessible to a large part of the population (Anusavice).. There is a large amount of gold in its composition, as $40 \%$ of its weight is composed of this type of metal. They are single-phase and easy to handle, except for gold-platinum-zinc alloys (Au-Pt-Zn) (Hensten-Pettersen, 1992; Wataha, 2002). These alloys will almost always have oxide builders next to their composition to increase their adhesive properties to porcelain such as indium, gallium, tin and iron (Wataha \& Messer, 2004).

Noble alloys have gold $(\mathrm{Au})$ and palladium $(\mathrm{Pd})$ in their main composition and are commonly associated with non-noble metals, such as copper $(\mathrm{Cu})$, gallium $(\mathrm{Ga})$ and cobalt (Co), which makes the alloy with shades dark (Wataha, 2002). Golden alloys are widely used in dentistry due to their low corrosion properties and good marginal adaptation, however their use in 
MATOS, J. D. M.; DOS SANTOS, A. C. M.; NAKANO, L. J. N.; DE VASCONCELOS, J. E. L.; ANDRADE, V. C.; NISHIOKA, R. S.; BOTTINO, M. A. \& LOPES, G. R. S. Metal alloys in dentistry: an outdated material or required for oral rehabilitation? Int. J. Odontostomat., 15(3):702-711, 2021.

Table II. Types of metal alloys and their main indications.

\begin{tabular}{|c|c|c|c|}
\hline Type I & Soft Alloy & & $\begin{array}{l}\text { They are weak and soft, being useful in areas not subject to } \\
\text { occlusal stresses. They are not widely used (Anusavice, 2013). }\end{array}$ \\
\hline Type II & MediumAlloy & & $\begin{array}{l}\text { They are used for inlays and onlays, in which there is a possibility to } \\
\text { bumish the edges to i ncrease the strength of the restorations } \\
\text { (Asakura et al., 2012; Anusavice, 2013). }\end{array}$ \\
\hline Type III & Hard Alloy & & $\begin{array}{l}\text { They are used in inlays, onlays, three-quarter crowns, retainers and } \\
\text { ponticsof fixed prosthodontics, where burnishing is less important } \\
\text { than resistance (Hu et al., 2010; Anusavice, 2013). }\end{array}$ \\
\hline Type IV & Extra Hard Alloy & & $\begin{array}{l}\text { They are hard and not ductile, being indicated in regions of high } \\
\text { tension as removable partial denture. They are not us ed extensively } \\
\text { due to cost (Sun et al., 2009; Anusavice, 2013). }\end{array}$ \\
\hline Type V & $\begin{array}{l}\text { Alloy for metal-ceramic } \\
\text { (copings) }\end{array}$ & restorations & $\begin{array}{l}\text { They are used for metal-ceramic restorations (copings) (Anusavice, } \\
\text { 2013; Rahman et al., 2019). }\end{array}$ \\
\hline
\end{tabular}

metalloceramic restorations is difficult due to the gold not producing enough oxides that are favorable to the adhesion of porcelain (Wataha, 2002; Romão et al., 2018; Matos et al., 2020). The limitation is in the greatest probability of suffering deformations at the moment when the porcelain is being melted, as they have low elastic modulus, consequently, their resistance is lower, being contraindicated in extensive restorations (Suansuwan \& Swain, 2001; Roberts et al.) (Table III).

Basic metal alloys are nickel-chromium (Ni-Cr), cobalt-chromium (Co-Cr) which have low cost, high modulus of elasticity, high strength, low flexibility, high melting temperature and low density (Okuno et al.; Vallittu \& Kokkonen). Titanium is also included in this class, being classified in its pure form as a basic metal and in the form of alloy as non-base metal (Takeuchi et al., 2020). However, basic alloys also have disadvantages, such as high hardness, which makes it difficult to finish prosthetic parts and restorative materials, porcelain pigmentation and low corrosion resistance in relation to noble alloys (Tkachenko et al.) (Table IV).

The casting process of the alloys is extremely important for its use, since during the process it is necessary to know the correct melting temperature due to the particularity for each type of alloy components, in which correct handling and techniques are required (Wataha \& Messer). Laboratory procedures have been improved and components added to porcelain to optimize metalloceramic restorations, such as leucite, which in the early 1960s was incorporated into porcelain with the proposal of making the degree of thermal expansion between them and metal alloys more compatible (Wataha, 2002; Romão et al.; Matos et al.).

Castability is of great importance due to the fine structures that are related to the manufacturing process (de Oliveira Bauer et al.). An example is Ni-Cr alloys, where beryllium $(\mathrm{Be})$ plays a very important role in the process due to a decrease in melting temperature and an increase in fluidity (Okuno et al.; Vallittu \& Kokkonen). In Co-Cr alloys, molybdenum (Mo) is added to decrease the thermal expansion coefficient and ruthenium $(R u)$ is used to improve its meltability (Wataha, 2002).

Interesting to elucidate with regard to the softener heat treatment, it must follow a specific protocol, in which after the casting step, the ring of the centrifuge is removed, waiting until the alloy loses its red color, and then the ring is immersed in cold water, causing a rapid cooling through a thermal shock (Callister Junior; Anusavice). Then, the hardening heat treatment can be carried out through three steps, the first is placing the restoration (ring) in the oven at a temperature of $450^{\circ} \mathrm{C}$, for five minutes, immediately after the oven is turned off, and wait to reach a temperature of $250^{\circ} \mathrm{C}$, subsequently immersing the ring in cold water for 15 minutes (Callister Junior; Anusavice). The second method is to place the ring in the oven at $370^{\circ} \mathrm{C}$ for 15 minutes, then it is removed from the oven and cooled slowly (Callister Junior; Anusavice; Chain). The third method, consists of the casting of the ring, with subsequent cooling at room temperature (Callister Junior; Anusavice; Chain).

With regard to titanium alloys, it is possible to highlight the greatest limitations in comparison to other alloys, due to their high melting temperature and low density, which require special techniques and complex equipment for their use, in addition to requiring porcelain with a low thermal coefficient, with temperature below the transition temperature of titanium itself for metalloceramic restorations (Hanawa, 2019; Koizumi et al.). However, titanium has satisfactory properties that promote its use in the medical / dental field, such as biocompatibility with bone tissues, has excellent resistance to corrosion (compared to other metallic alloys) and also resistance 
MATOS, J. D. M.; DOS SANTOS, A. C. M.; NAKANO, L. J. N.; DE VASCONCELOS, J. E. L.; ANDRADE, V. C.; NISHIOKA, R. S.; BOTTINO, M. A. \& LOPES, G. R. S. Metal alloyS in dentistry: an outdated material or required for oral rehabilitation? Int. J. Odontostomat., 15(3):702-711, 2021.

Table III. Main chemical elements of metal alloys and their applicability in dentistry.

\begin{tabular}{|c|c|}
\hline Metal alloy constituent elements & Applicability in Dentistry \\
\hline Aluminum & It increases tensile strength and ductility, especially when associated with nickel (Morrel, 1996). \\
\hline Beryllium & $\begin{array}{l}\text { It reduces the melting temperature of the alloy (100 degrees Celsius), the ductility and the } \\
\text { resistance to corrosion (Zwilsky \& Langer, 2001). }\end{array}$ \\
\hline Carbon & $\begin{array}{l}\text { The surface hardness of the alloy increases when it is above } 0.2 \% \text {, the alloy becomes very } \\
\text { hard, so the casting process is impossible to occur (Harper, 2000). }\end{array}$ \\
\hline Cobalt & It increases the resistance (hardness) and elasticity (Vallittu \& Kokkonen, 1995; Morrel, 1996). \\
\hline Copper & $\begin{array}{l}\text { It increases the resistance by up to } 20 \% \text {, increases the hardness and reduces the melting zone } \\
\text { of the alloy, allowing greater homogeneity of the alloy (Morrel, 1996). }\end{array}$ \\
\hline Chrome & $\begin{array}{l}\text { It increases the resistance to loss of shine and corrosion, and should not exce ed } 29 \% \text { (Okuno } \\
\text { et al., 1989; Callister Junior, 1994). }\end{array}$ \\
\hline Gold & $\begin{array}{l}\text { It provides resistance to oxidation and increases the ductility and malleability of the alloy (Okuno } \\
\text { et al., 1989; Wataha, 2002). }\end{array}$ \\
\hline Silver & $\begin{array}{l}\text { It improves the alloy's ductility, neutralizes the reddish color conferred by copper and facilitates } \\
\text { bumishing (Wataha \& Messer, 2004). }\end{array}$ \\
\hline Platinum and Palladium & $\begin{array}{l}\text { It provides greater resistance to oxidation and corrosion, increasing the strength and hardness } \\
\text { of the alloy (Callister Junior, 1994; Morrel, 1996; Wataha \& Messer, 2004). }\end{array}$ \\
\hline Tin & It increases malleability (Callister Junior, 1994; Morrel, 1996). \\
\hline Molybdenum & $\begin{array}{l}\text { When it has } 3 \text { to } 6 \% \text {, it increases resistance to corrosion and increases ductibility (Callister } \\
\text { Junior, 1994; Morrel, 1996). }\end{array}$ \\
\hline Manganese & Increases the flow of the alloy (Okuno et al., 1989; Wataha, 2002). \\
\hline Nickel & It increases the malleability of the alloy (Okuno et al., 1989; Callister Junior, 1994). \\
\hline Niobium & $\begin{array}{l}\text { It acts as an inducer of bone formation, cell growth and corrects deleterious bone defects } \\
\text { (Johansson \& Albrektsson, 2001; Ribeiro et al., 2009). }\end{array}$ \\
\hline Titanium & $\begin{array}{l}\text { It acts as a prosthetic rehabilitation material, replacing a lost dental element (Hanawa, 2019; } \\
\text { Koizumi et al., 2019). }\end{array}$ \\
\hline Zinc & It acts as an antioxidant agent (Morreu, 1996; Wataha \& Messer, 2004). \\
\hline Zirconia & $\begin{array}{l}\text { It acts as an aesthetic rehabilitation material, being used in fixed dentures on teeth and on } \\
\text { implants (Piconi \& Maccauro, 1999; Mehjabeen et al., 2018; Matos et al., 2020). }\end{array}$ \\
\hline
\end{tabular}

to attacks by acids, minerals or chlorides (Osman et al., 2013).

Another alloy that has shown prominence are those composed of niobium $(\mathrm{Nb})$, in turn presenting the same number of protons and electrons, about forty-one in their composition and atomic mass $92.9 \mathrm{u}$ (Johansson \& Albrektsson, 2001). Niobium has physical and chemical properties similar to that of the chemical element tantalum and, therefore, both are difficult to distinguish (Johansson \& Albrektsson). Tantalum is widely used in metal alloys, especially in the production of special steels used in pipeline tubes and in the production of fluid-conducting tubes, under normal conditions it presents itself as a white solid (Johansson \& Albrektsson; Ribeiro et al., 2009). Although these alloys contain a maximum of $0.1 \%$ niobium, this small percentage gives a high mechanical resistance to steel (Johansson \& Albrektsson; Ribeiro et al.). The thermal stability of super alloys that contain niobium is important for the production of dental engines and in various superconducting materials (Ribeiro et al.).
Table IV. Distribution of mechanical properties of materials.

\begin{tabular}{lcc}
\hline \multicolumn{1}{c}{ Materials } & $\begin{array}{c}\text { Elastic modulus } \\
(\mathrm{GPa})\end{array}$ & $\begin{array}{c}\text { Poisson } \\
\text { ratio }\end{array}$ \\
\hline Zirconia (Piconi \& Maccauro, 1999) & 220 & 0.30 \\
Titanium (Osman et al., 2013) & 110 & 0.34 \\
Niobium (Johansson \& Albrektsson, 2001) & 103 & 0.38 \\
Aluminum (Morrel, 1996) & 69 & 0.33 \\
Beryllium (Zwilsky \& Langer, 2001) & 128 & 0.25 \\
Carbon (Harper, 2000) & 220 & 0.25 \\
Cobalt (Morrel, 1996) & 209 & 0.31 \\
Copper (Morrel, 1996) & 115 & 0.34 \\
Chrome (Callister Junior, 1994) & 286 & 0.21 \\
Gold (Morrel, 1996) & 77 & 0.42 \\
Silver (Callister Junior, 1994) & 84 & 0.36 \\
Platinum and Palladium (Morrel, 1996) & 171 & 0.39 \\
Tin (Morrel, 1996) & 44.3 & 0.33 \\
Molybdenum (Morrel, 1996) & 320 & 0.32 \\
Manganese (Callister Junior, 1994) & 198 & 0.29 \\
Nickel (Morrel, 1996) & 204 & 0.31 \\
Zinc (Morrel, 1996) & 104.5 & 0.25
\end{tabular}

Niobium in the form of oxide (Nb2O5) is a semiconductor with numerous applications in optical devices and in heterogeneous catalysis, as an active phase (Zanetta-Barbosa et al., 2002a). All of these destinations are noble, but could be further refined, so other applications of these alloys include chemistry, biology, bioengineering, dentistry and medicine 
MATOS, J. D. M.; DOS SANTOS, A. C. M.; NAKANO, L. J. N.; DE VASCONCELOS, J. E. L.; ANDRADE, V. C.; NISHIOKA, R. S.; BOTTINO, M. A. \& LOPES, G. R. S. Metal alloyS in dentistry: an outdated material or required for oral rehabilitation? Int. J. Odontostomat., 15(3):702-711, 2021.

(Zanetta-Barbosa et al., 2002b). With regard to dentistry, it is known that through chemical reactions the material becomes more reactive and with special properties that allows a wide use in dentistry, whether in bleaching gels, dentifrices, making structures for oral rehabilitation and surface treatment of implants (Zanetta-Barbosa et al., 2002a,b).

Laboratory studies have shown that this biomaterial is non-toxic, biocompatible, bactericidal, low elastic modulus, high corrosion resistance, thermodynamic stability, adequate mechanical properties, low toxicity and no negative behavior towards the living organism (Johansson \& Albrektsson; Zanetta-Barbosa et al., 2002a,b; Ananth et al., 2018). In addition, its excellent physical-chemical properties can be highlighted, especially when evaluating the cell viability of this metallic alloy, as the material has a high capacity to enhance the induction of bone formation, cell growth and corrective of deleterious bone defects, it especially owes its bioactivity property (Kokubo et al., 2003; Miyazaki, 2008). But not only that, the ability to establish a direct reaction with bone tissue can also be highlighted, producing an effect of tissue and bone regenerator and with maximum antimicrobial effect (Anselme, 2000).

In addition, niobium, like titanium, has a protective surface oxide layer (Jelínek et al., 2017). This oxide is niobium pentoxide, which forms quickly and spontaneously when the metal is exposed in oxygen-containing media (Bleckenwegner et al., 2017). This layer, in turn, is considered stable and responsible mainly for the biocompatibility of the alloy, thus being widely used in antiallergic coatings of implantsupported prostheses (Bleckenwegner et al.; Jelínek et al.). However, new studies have demonstrated the addition of oxides on the surface of these materials allowing it to stimulate the interaction with bone tissue, so that the osseointegration between the implant and the tissue is improved, resulting in a reduction in recovery time of the patient (Ficarro et al., 2008; Tolosa et al., 2018; Fernandes et al., 2019a,b).Some surface characteristics that improve interaction with the biological environment and promote better osseointegration are: topography, roughness, porosity, hydrophilicity, oxide crystallinity and surface chemical composition (Eisenbarth et al., 2006; Ficarro et al.; Tolosa et al.). Therefore, the surface playing a fundamental role in the responses of the implants to biological tissues and often, due to adequate surface treatments, exhibit different characteristics in relation to the original substrate (Nowak \& Ziolek, 1999; Ficarro et al.).
In the oral environment, the alloys must exercise their most favorable properties efficiently so that the patient's rehabilitation does not damage their oral health, both in aesthetic and functional aspects, thus, properties such as corrosion resistance are essential factors when choosing a type alloy (Johansson \& Albrektsson; Zanetta-Barbosa et al., 2002a). It is known that noble alloys in general are less influenced by external chemical agents, being less corroded (Fernandes et al., 2019a,b). Alloys with silver (Ag) in their composition, a non-noble element, react chemically with air, water and sulfur, generating dark substances such as silver sulfate (Tchaplyguine et al., 2018; Oleshko et al., 2019). Titanium is the metal that has better properties against corrosion, since in its surface layer it is formed by stable oxides that protect the material from this type of destruction (Sri et al., 2019; Mello et al., 2019).

The search for oral rehabilitation procedures as a way to guarantee the proper function of oral structures allowed the metal alloys to play an important role in the patient's quality of life, especially when they are applied in implant-supported prostheses, removable partial prostheses, fixed prostheses, restorations in dentistry and unitary implants (Wataha, 2002; de Oliveira Bauer et al.; Roberts et al.). It is important to note that the applicability of the different types of alloys is specific to each case (Wataha, 2002).

The noble alloys present in the market today were the first to be used by dentists in clinical practice, which promoted the evolution of research (Roberts et al.). The development of science has allowed the emergence of alternative alloys such as basic metal alloys, which have a lower cost (Wataha, 2002; Anusavice).

For the correct use of metal alloys, it is necessary to evaluate their properties, with mechanical resistance, ease of casting and low corrosion being the most relevant factors at the moment of choice (Shillingburg, 1998). Each type of alloy has qualities and defects, so the dental surgeon and dental technician must have the discretion to choose them in each specific case, evaluating the properties of each material (Wataha, 2002; Anusavice).

When selecting high noble alloys that have a large amount of gold in their composition, production costs should be considered, as they have a high value (Schuster, 1996). However, this alloy when evaluated from the point of view of biological safety has excellent advantages, and there is no doubt that it is the most 
biocompatible with oral tissues (Roberts et al.). High noble alloys, generally present in their composition other metals that alter their properties, such as, for example, gallium that reduces its melting temperature in metal-ceramics, as well as indium, tin and iron that increase the formation of oxides and promote greater adhesion porcelain (Matos et al.).

Widely used in dentistry due to their low cost and excellent properties, basic metal alloys are on the market with great acceptance from the dental community due to their superior mechanical properties, such as high mechanical strength values and high hardness, in addition to being more resistant to deformations at high temperatures (Sadowsky, 2020). Because of this, these alloys were widely introduced in prosthetic rehabilitation and metal-ceramic restorations (Wataha, 2002; de Oliveira Bauer et al.; Roberts et al.).

The use of metal alloys for rehabilitation treatments has great advantages, since its wide use has promoted several studies for a better understanding of the materials used and improvement of existing limitations (de Oliveira Bauer et al.; Reitemeier et al., 2006; Roberts et al.; Jesus et al., 2020). In this context, a well-known material is highlighted for being considered the white metal of dentistry: zirconia (Piconi \& Maccauro, 1999; Matos et al.).This metal presents as raw material the minerals of zirconium ( $\mathrm{ZrSiO} 4)$ and baddelyite ( $\mathrm{B}-\mathrm{ZrO} 2)$ (Hanawa; Campos et al., 2020). Thus, zirconium is intended for an application as a metal, while oxide white zirconium crystalline is designated as dental ceramic (Piconi \& Maccauro; Matos, 2020).

Zirconia oxide appears as a transition metal in the periodic table, having a dark blue color in its raw form (Piconi \& Maccauro; Matos et al.). After laboratory procedures, this metal acquires its crystalline shape, modifying its properties and showing the characteristic aspect in white, allowing the opacification of darkened dental remnants and infrastructures, in addition to masking in areas of thin periodontal tissue, which highlights its potential as a superior aesthetic metal (Shi et al., 2016; Sadowsky). The zirconia metal alloy has good resistance to corrosion in acidic environments, which increases its applicability in relation to other metals (Tkachenko et al.; Mehjabeen et al., 2018). The non-toxic metal characteristic is favorable and guarantees a bio-inert behavior when intimate with oral structures, therefore, it allows its use as a structural component of dental products, from restorative materials to dental implants (Wataha, 2002; Nie et al., 2014). Some of the different metallic alloys sold have adverse hypersensitivity effects, with zirconia as a safe alternative to cases of allergic sensitivity (Rinke et al., 2013; Sadowsky).

The choice of materials for application in the oral environment must consider factors such as microbial adhesion to the product of choice and a low thermal conductivity (Campos et al.; Matos et al.). Zirconia shows reduced bacterial growth on its surface, which guarantees a reduction in complications in soft and hard tissues, as well as a longevity of treatments, in addition to preventing the spread of thermal stimuli to support structures (Chen et al., 2016; Hanawa). The high hardness, good mechanical resistance and less wear compared to titanium alloys allow to define zirconia as a material with excellent physical properties (Osman et al.; Mehjabeen et al.; Hanawa).

The ability to osseointegrate and excellent adhesion to soft tissues are important characteristics that increase the use of zirconia alloys, as it allows better clinical performances and durability to the treatments performed (Matos et al.; Sadowsky). Considering the need for materials with excellent properties for use as new rehabilitation resources, zirconia is able to meet these requirements and play great potential among the other available metals (Roberts et al.; Rinke et al.; Hanawa). The use of zirconia reinforces the applicability of metal alloys in relation to other existing dental materials and allows us to understand that these resources are still viable alternatives in rehabilitation treatments because they present high advantages, accessible cost and mastery of the techniques of use (McLean; Kokubo et al.; Matos).

\section{CONCLUSIONS}

It can be concluded from this study that several alloys and metals are available for the dental market each presenting advantages and disadvantages, mainly based on its specific composition. Continuous research and development are resulting in the production of new technologies and products, giving dental surgeons even more options in the design and manufacture of restorations using metal alloys and understanding that these resources will still be viable alternatives in oral rehabilitations. The use of zirconia reinforces the applicability of metal alloys in relation to 
MATOS, J. D. M.; DOS SANTOS, A. C. M.; NAKANO, L. J. N.; DE VASCONCELOS, J. E. L.; ANDRADE, V. C.; NISHIOKA, R. S.; BOTTINO, M. A. \& LOPES, G. R. S. Metal alloyS in dentistry: an outdated material or required for oral rehabilitation? Int. J. Odontostomat., 15(3):702-711, 2021.

other existing dental materials and allows us to understand that these resources will still be viable alternatives in rehabilitation treatments. However, further studies on metal alloys are needed to better understand this subject.

\section{ACKNOWLEDGMENTS}

This work was supported by the São Paulo Research Foundation (FAPESP - grant numbers 2019/ 24903-6).

MATOS, J. D. M.; DOS SANTOS, A. C. M.; NAKANO, L. J. N.; DE VASCONCELOS, J. E. L.; ANDRADE, V. C.; NISHIOKA, R. S.; BOTTINO, M. A. \& LOPES, G. R. S. Aleaciones metálicas en odontología: ¿un material excedido o necesario para la rehabilitación oral?. Int. J. Odontostomat., 15(3):702-711, 2021.

RESUMEN: El presente trabajo tuvo como objetivo describir a través de una revisión de la literatura, los principales tipos de aleaciones nobles y no nobles utilizados en odontología buscando identificar los mecanismos de adhesión, composiciones y propiedades mecánicas, así como reflejar su aplicabilidad como recurso rehabilitador en la actualidad. Realizamos una búsqueda bibliográfica em las principales bases de datos de salud PUBMED (www.pubmed.gov) y Scholar Google (www.scholar. google.com.br), en la que se recopilaron estudios publicados desde 1971 hasta 2021. Estudios de laboratorio, informes de casos, revisiones sistemáticas y bibliográficas, que se desarrollaron en individuos vivos. Sin embargo, se excluyeron los artículos que no trataban sobre aleaciones metálicas y su uso en odontología. Se pudo observar que todos los trabajos presentaban las aleaciones metálicas y sus principales propiedades indicando que se estas dividen en tres tipos principales: aleaciones altamente nobles, aleaciones nobles y aleaciones de metales base que difierenen sus niveles de metales nobles constituyentes. Hay varias aleaciones y metales disponibles para el mercado dental, cada uno presenta ventajas y desventajas, principalmente en función de su composición específica. La investigación y el desarrollo continuo están dando como resultado la producción de nuevas tecnologías y productos, brindando a los cirujanos dentistas aún más opciones en el diseño y fabricación de las restauraciones, utilizando aleaciones metálicas $\mathrm{y}$, permite concluir que estos recursos seguirán siendo alternativas viables en los tratamientos de rehabilitación. Sin embargo, se necesitan más estudios sobre el tema abordado en el trabajo, para una comprensión más profunda del tema.

PALABRAS CLAVE: aleaciones dentales, aleaciones de cerámica y metal, odontologia, investigación dental.

\section{REFERENCES}

Akagi, K.; Okamoto, Y.; Matsuura, T. \& Horibe, T. Properties of test metal ceramic titanium alloys. J. Prosthet. Dent., 68(3):4627, 1992.

Ananth, K. P.; Sun, J. \& Bai, J. An innovative approach to manganese-substituted hydroxyapatite coating on zinc OxideCoated 316L SS for implant application. Int. J. Mol. Sci., 19(8):2340, 2018.

Anselme, K. Osteoblast adhesion on biomaterials. Biomaterials, 21(7):667-81, 2000.

Anusavice, K. J.; Phillips, R. W.; Shen, C. \& Rawls, H. R. Phillips' Science of Dental Materials. 12th ed. St. Louis (Mo.), Elsevier/ Saunders, 2013.

Asakura, M.; Kominami, Y.; Hayashi, T.; Tsuruta, S. \& Kawai, T. The effect of zinc levels in a gold-based alloy on porcelainmetal bonding. Dent. Mater., 28(5):e35-41, 2012.

Bleckenwegner, P.; Mardare, C. C.; Cobet, C.; Kollender, J. P.; Hassel, A. W. \& Mardare, A. I. Compositionally dependent nonlinear optical bandgap behavior of mixed anodic oxides in niobium-titanium system. ACS Comb. Sci., 19(2):121-9, 2017.

Callister Junior, W. D. Materials Science and Engineering: An Introduction. 3th ed. New York, John Wiley \& Sons, 1994.

Campos, T. M. B.; Ramos, N. C.; Matos, J. D. M.; Thim, G. P.; Souza, R. O. A.; Bottino, M. A.; Valandro, L. F. \& Melo, R. M. Silica infiltration in partially stabilized zirconia: Effect of hydrothermal aging on mechanical properties. J. Mech. Behav. Biomed. Mater., 109:103774, 2020.

Chain, M. C. Materiais Dentários. São Paulo, Artes Médicas, 2013.

Chen, J.; Tan, L.; Yu, X.; Etim, I. P.; Ibrahim, M. \& Yang, K. Mechanical properties of magnesium alloys for medical application: A review. J. Mech. Behav. Biomed. Mater., 87:6879, 2018.

Chen, Y. W.; Moussi, J.; Drury, J. L. \& Wataha, J. C. Zirconia in biomedical applications. Expert Rev. Med. Devices, 13(10):94563, 2016.

de Oliveira Bauer, J. R.; Calheiros, F. C.; Braga, R. R. \& Miranda Junior, W. G. Ligas para restaurações metalocerâmicas: uma revisão da literatura. Rev. Fac. Odont., 9(2):83-7, 2004.

Eisenbarth, E.; Velten, D.; Müller, M.; Thull, R. \& Breme, J. Nanostructured niobium oxide coatings influence osteoblast adhesion. J. Biomed. Mater. Res. A, 79(1):166-75, 2006.

Espevik, S.; Oilo, G. \& Lodding, A. Oxidation of noble metal alloys for porcelain veneer crowns. Acta Odontol. Scand., 37(6):3238, 1979.

Fernandes, S. L.; Affonço, L. J.; Junior, R. A. R.; Silva, J. H. D.; Longo, E. \& Graeff, C. F. O. Niobium oxide films deposited by reactive sputtering: effect of oxygen flow rate. J. Vis. Exp., 28:(151), 2019a.

Fernandes, S. L.; Albano, L. G. S.;Affonço, L. J.; Silva, J. H. D.; Longo, E. \&Graeff, C. F. O. Exploring the properties of niobium oxide films for electron transport layers in perovskite solar cells. Front. Chem., 7:50, 2019b.

Ficarro, S. B.; Parikh, J. R.; Blank, N. C. \& Marto, J. A. Niobium (V) oxide (Nb2O5): application to phosphoproteomics. Anal. Chem., 80(12):4606-13, 2008.

Hampel, A. C. Rare Metals Handbook. 2nd ed. New York, Krieger, 1971.

Hanawa, T. Zirconia versus titanium in dentistry: A review. Dent. Mater. J., 39(1):24-36, 2019.

Harper, C. A. Modern plastics handbook. McGraw Hill Professional, 1-996, 2000.

Hensten-Pettersen, A. Casting alloys: side-effects. Adv. Dent. Res., 6:38-43, 1992. 
Hu, Y. D.; Wu, X. M.; Yu, H. Y. \& Ma, T. Y. Comparison of the influences of gold alloy metal crown and ni-cr alloy metal crown on gingival health. Zhongguo Yi Xue Ke Xue Yuan Xue Bao, 32(3):269-71, 2010.

Jelínek, M.; Vane`k, P.; Tolde, Z.; Buixaderas, E.; Kocourek, T.; Studnička, V.; Drahokoupil, J.; Petzelt, J.; Remsa, J. \& Tyunina, M. PLD prepared bioactive $\mathrm{BaTiO} 3$ films on TiNb implants. Mater. Sci. Eng. C Mater. Biol. Appl., 70(Pt. 1):334-9, 2017.

Jesus, R. H.; Furlam, B. C.; Martinusse, C. M.; Inácio, H. C. V.; Matos, J. D. M.; Nakano, L. J. N.; Ortiz, L. P. N.; Bottino, M. A. \& Maciel, L. C. Influence of Acid Etching on Bond Strength Between Feldspathic Ceramics and Resin Cement. Rev. Bras. Odontol., 77(1):e1769, 2020.

Johansson, C. B. \& Albrektsson, T. A removal torque and histomorphometric study of commercially pure niobium and titanium implants in rabbit bone. Clin. Oral Implants Res., 2(1):24-9, 1991.

Koizumi, H.; Takeuchi, Y.; Imai, H.; Kawai, T. \& Yoneyama, T. Application of titanium and titanium alloys to fixed dental prostheses. J. Prosthodont. Res., 63(3):266-70, 2019.

Kokubo, T.; Kim, H. M. \& Kawashita, M. Novel bioactive materials with different mechanical properties. Biomaterials, 24(13):216175, 2003.

Marklund, S.; Bergman, B.; Hedlund, S. O. \& Nilson, H. An intraindividual clinical comparison of two metal-ceramic systems: a 5-year prospective study. Int. J. Prosthodont., 16(1):70-3, 2003

Matos, J. D. M. Avaliação do Desgaste Fisiológico da Camada de Caracterização Aplicada sobre Cerâmicas Odontológicas. São Paulo, Universidade Estadual Paulista (UNESP), Instituto de Ciência e Tecnologia, São José dos Campos. Programa de Pós Graduação em Odontologia Restauradora, 2020.

Matos, J. D. M.; Nakano, L. J. N.; Bottino, M. A.; Jesus, R. H. \& Maciel, L. C. Currentconsiderations for dental ceramics and the irrespective union systems. Rev. Bras. Odontol., 77(1):e1768, 2020.

McLean, J. W. The Science and Art of Dental Ceramics. Chicago, Quintessence, 1980.

Mehjabeen, A.; Song, T.; Xu, W.; Tang, H.P. \& Qian, M. Zirconium alloys for orthopaedic and dental applications. Adv. Eng. Mater., 20(9):1800207, 2018.

Mello, D. C. R.; Oliveira, J. R.; Cairo, C. A. A.; Ramos, L. S. B.; Vegian, M. R. D. C.; Vasconcellos, L. G. O.; Oliveira, F. E.; Oliveira, L. D. \& Vasconcellos, L. M. R. Titanium alloys: in vitro biological analyzes on biofilm formation, biocompatibility, cell differentiation to induce bone formation, and immunological response. J. Mater. Sci. Mater. Med., 30(9):108, 2019.

Miyazaki, T. Development of bioactive materials based on bonebonding mechanism on metal oxides. J. Ceram. Soc. Jpn., 116(1350):260-264, 2008.

Morrel, R. Measuring Elastic Properties of Advanced Technical Ceramics $-A$ review. In: NPL Report CMMT (A) 42. Teddington, National Physical Laboratory, 1996. pp.41.

Nie, L.; Zhan, Y.; Liu, H. \& Tang, C. Novel b-type Zr-Mo-Ti alloys for biological hard tissue replacements. Mater. Des., 53:8-12, 2014.

Nowak, I. \& Ziolek, M. Niobium compounds: preparation, characterization, and application in heterogeneous catalysis. Chem. Rev., 99(12):3603-24, 1999.

Okuno, O.; Tesk, J. A. \& Penn R. Mesh monitor casting of Ni-Cr alloys: element effects. Dent. Mater., 5(5):294-300, 1989.

Oleshko, O.; Deineka, V. V.; Husak, Y.; Korniienko, V.; Mishchenko, O.; Holubnycha, V.; Pisarek, M.; Michalska, J.; Kazek-Ke sik, A.; Jakóbik-Kolon, A.; Simka, W. \& Pogorielov, M. Ag nanoparticle-decorated oxide coatings formed via plasma electrolytic oxidation on ZrNb alloy. Materials (Basel), 12(22):3742, 2019.
Osman, R. B.; Elkhadem, A. H.; Ma, S. \& Swain, M. V. Titanium versus zirconia implants supporting maxillary overdentures: three-dimensional finite element analysis. Int. J. Oral Maxillofac. Implants, 28(5):e198-208, 2013.

Piconi, C. \& Maccauro, G. Zirconia as a ceramic biomaterial. Biomaterials, 20(1):1-25, 1999.

Rahman, M. A; Rahman, M. M.; Rahman, M. M.; Hossain, M. A.; Tauhid, F.; Paul, P. K.; Abdullah, A. N. \& Amin, M. R. Evaluation of corrosion and tarnishing of intra-oral nickel chromium and gold-alloy cast crown. Mymensingh Med. J., 28(4):862-5, 2019.

Reitemeier, B.; Hänsel, K.; Kastner, C. \& Walter, M. H. Metalceramic failure in noble metal crowns: 7-year results of a prospective clinical trial in private practices. Int. J. Prosthodont., 19(4):397-9, 2006.

Ribeiro, A. L.; Junior, R. C.; Cardoso, F. F.; Filho, R. B. \& Vaz, L. G. Mechanical, physical, and chemical characterization of Ti$35 \mathrm{Nb}-5 \mathrm{Zr}$ and Ti-35Nb-10Zr casting alloys. J. Mater. Sci. Mater. Med., 20(8):1629-36, 2009.

Rinke, S.; Schäfer, S.; Lange, K.; Gersdorff, N. \& Roediger, M. Practice-based clinical evaluation of metal-ceramic and zirconia molar crowns: 3-year results. J. Oral Rehabil., 40(3):228-37, 2013.

Roberts, H. W.; Berzins, D. W.; Moore, B. K. \& Charlton, D. G. Metal-ceramic alloys in dentistry: a review. J. Prosthodont., 18(2):188-94, 2009.

Romão, R. M.; Lopes, G. R. S.; Matos, J. D. M.; Lopes, G. R. S.; Vasconcelos, J. E. L. \& Fontes, N. M. Causes of failures in ceramic veneers restorations: A literature review. Int. J. Adv. Res., 6(4):896-906, 2018.

Sadowsky, S. J. Has zirconia made a material difference in implant prosthodontics? A review. Dent. Mater., 36(1):1-8, 2020.

Schuster, G. S.; Lefebvre, C. A.; Wataha, J. C. \& White, S. N. Biocompatibility of posterior restorative materials. J. Calif. Dent. Assoc., 24(9):17-31, 1996.

Shi, J. Y.; Li, X.; Ni, J. \& Zhu, Z. Y. Clinical evaluation and patient satisfaction of single zirconia-based and high-noble alloy porcelain-fused-to-metal crowns in the esthetic area: $A$ retrospective cohort study. J. Prosthodont., 25(7):526-30, 2016.

Shillingburg, J. R. Fundamentos de Prótese Fixa. 3rd ed. São Paulo, Quintessence, 1998

Sri, M.; Vishnu, D.; Sure, J.; Liu, Y.; Vasant-Kumar, R. \& Schwandt, C. Electrochemical synthesis of porous $\mathrm{Ti}-\mathrm{Nb}$ alloys for biomedical applications. Mater. Sci. Eng. C Mater. Biol. Appl., 96:466-78, 2019.

Suansuwan, N. \& Swain, M. V. Determination of elastic properties of metal alloys and dental porcelains. J. Oral Rehabil., 28(2):133-9, 2001

Sun, W. G.; Liu, X. H.; Zhang, L.; Zhang, C.; Xie, M. Y. \& Zhou, W. $\mathrm{J}$. Clinical evaluation of the effect of gold alloy and $\mathrm{Ni}-\mathrm{Cr}$ alloy porcelain fused metal crown restorations. Shanghai Kou Qiang Yi Xue, 18(1):40-3, 2009.

Takeuchi, Y.; Tanaka, M.; Tanaka, J.; Kamimoto, A.; Furuchi, M. \& Imai, $\mathrm{H}$. Fabrication systems for restorations and fixed dental prostheses made of titanium and titanium alloys. J. Prosthodont. Res., 64(1):1-5, 2020.

Tchaplyguine, M.; Zhang, C.; Andersson, T. \& Björneholm, O. AgCu oxide nanoparticles with high oxidation states: towards new high Tc materials. Dalton Trans., 47(46):16660-7, 2018.

Tkachenko, S.; Datskevich, O.; Kulak, L.; Jacobson, S.; Engqvist, H. \& Persson, C. Wear and friction properties of experimental Ti-Si-Zr alloys for biomedical applications. J. Mech. Behav. Biomed. Mater., 39:61-72, 2014.

Tolosa, A.; Fleischmann, S.; Grobelsek, I.; Quade, A.; Lim, E. \& Presser, V. Binder-free hybrid titanium-niobium oxide/carbon nanofiber mats for lithium-ion battery electrodes. ChemSusChem,11(1):159-70, 2018. 
MATOS, J. D. M.; DOS SANTOS, A. C. M.; NAKANO, L. J. N.; DE VASCONCELOS, J. E. L.; ANDRADE, V. C.; NISHIOKA, R. S.; BOTTINO, M. A. \& LOPES, G. R. S. Metal alloys in dentistry: an outdated material or required for oral rehabilitation? Int. J. Odontostomat., 15(3):702-711, 2021.

Vallittu, P. K. \& Kokkonen, M. Deflection fatigue of cobalt-chromium, titanium, and gold alloy cast denture clasp. J. Prosthet. Dent., 74(4):412-9, 1995

Wataha, J. C. \& Messer, R. L. Casting alloys. Dent. Clin. North Am., 48(2):vii-viii, 499-512, 2004.

Wataha, J. C. Alloys for prosthodontic restorations. J. Prosthet. Dent. 87(4):351-63, 2002.

Wataha, J. C. Principles of biocompatibility for dental practitioners J. Prothest. Dent., 86(2):203-9, 2001.

Wolfaardt, J. F. \& Peters, E. The base metal alloy question in removable partial dentures--a review of the literature and a survey of alloys in use in Alberta. J. Can. Dent. Assoc., 58(2):146-51, 1992.

Zanetta-Barbosa, D.; Duarte, L. G. A. \& Gomide, H. A. Reação do tecido ósseo ao implante de corpos de nióbio. Estudo histológico em coelhos. RBC, 9(36):291-4, 2002b.

Zanetta-Barbosa, D.; Duarte, L. G. A. \& Gomide, H. A. Reações Teciduais ao implante de corpos de nióbio. Estudo histológico em ratos. Rev. ABO Nac., 10(3):160-4, 2002a.

Zavanelli, R. A. Corrosion-fatigue life of commercially pure titanium and Ti-6AL-4V alloys in different storage environments. J. Prosthet. Dent., 84:274-9, 2000.

Zwilsky, K. M. \& Langer, E. L. ASM Handbook volume 2, Properties and Selection: Nonferrous alloys and special purpose materials. ASM Int., 9(1):1-855, 2001.
Corresponding author:

Jefferson David Melo de Matos

D.D.S.; M.D.; Ph.D. Student

Post Graduate Student - Ph.D Program

Department of Dental Materials and Prosthodontics

São Paulo State University (Unesp)

Institute of Science and Technology

São José dos Campos - SP.

Avenida Engenheiro Francisco José Longo, 777/778

Jardim São Dimas

São José dos Campos - SP

BRAZIL

E-mail: matosjefferson19@gmail.com

ORCID: https://orcid.org/0000-0003-4507-0785 